\title{
YINYANG \\ Proses Relasi Gender Pada Single Parent dalam Membentuk Identitas Gender Anak
}

\author{
Camelia Arni Minandar ${ }^{1}$, Siti Komariah ${ }^{2}$, Tutin Aryanti ${ }^{3}$ \\ 1,2,3Universitas Pendidikan Indonesia, Bandung - Indonesia \\ Email Penulis: ${ }^{1}$ cameliawr@gmail.com, ${ }^{2}$ sitikomariah@upi.edu, ${ }^{3}$ tutin@upi.edu \\ Article Information

\begin{tabular}{llll}
\hline Submitted & $: 2021-03-29$ & Revision & $: 2021-11-17$ \\
Reviewed & $: 2021-10-06$ & Published & $: 2021-11-30$ \\
\hline
\end{tabular}

Abstract: The problem of the status of being a single parent who experiences a change in role and has a double burden in the formation of a child's gender identity, becomes a separate difficulty for single parents. The formation of gender identity itself is an important part of recognizing the concept of gender as a boy (masculine) or female (feminine) which is influenced by biological, social and cognitive factors during the socialization process of their parents. To describe this situation, this research study focuses on examinina how gender relations between children and single narents of

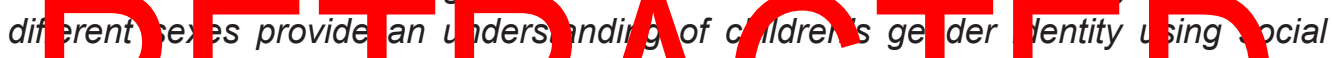
lea . he this s idy, at ativ ap ro ch was used base rew of he lin rat re, both th oreti al an 'er piric ' ( e res) Its s owe that, the proce ss of

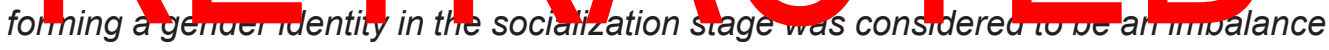
in the social learning process of gender identity. The domination of gender norms when the socialization of gender identity formation obscures the role of one gender, so that the meaning of gender is considered biased. The results showed that in single parent families, there tends to be an imbalance in the social learning process of gender identity because of the vacuum of gender roles. The domination of gender norms during the socialization of gender identity formation can obscure the role of one gender, so that the meaning of gender is considered biased.

Keywords: Gender identity, Gender relations, Single parent, Social learning theory.

Abstrak: Problematika status sebagai orang tua tunggal yang mengalami perubahan peran serta memiliki beban ganda dalam pembentukan identitas gender anak, menjadi kesulitan tersendiri bagi para orang tua tunggal. Pembentukan identitas gender sendiri merupakan bagian penting dalam mengenali konsep gender anak sebagai seorang 
laki-laki (maskulin) atau perempuan (feminin) yang dipengaruhi oleh faktor biologis, sosial dan kognitif selama proses sosialisasi dari orang tuanya. Untuk mendeskripsikan keadaan tersebut, studi penelitian ini berfokus mengkaji bagaimana relasi gender antara anak dan orang tua tunggal yang berbeda jenis kelamin dalam memberikan pemahaman mengenai identitas gender anak dengan menggunakan teori belajar sosial (social learning theory). Dalam penelitian ini digunakan pendekatan kualitatif berdasarkan tinjauan kritis dari literatur baik teoritis maupun empiris. Hasil penelitian menunjukan bahwa dalam keluarga orang tua tunggal, cenderung terjadi ketimpangan dalam proses pembelajaran sosial identitas gender karena adanya kekosongan peran gender. Adanya dominasi norma gender saat sosialisasi pembentukan identitas gender dapat mengaburkan peran salah satu gender, sehingga makna gender dianggap bias.

Kata Kunci: Identitas gender, Relasi gender, Orang tua tunggal, Teori belajar sosial

\section{Pendahuluan}

Pendidikan di dalam keluarga menjadi fondasi dasar bagi seorang anak. Proses hubungan orang tua baik ayah dan ibu dalam hubungan keluarga merupakan tempat sosialisasi primer dalam pembinaan dan internalisasi sistem nilai pada anak dari sejak dini hingga beranjak dewasa. Namun, di tengah-tengah masyarakat terdapat fenomena ketidaklengkapan unsur sebuah keluarga yang biasa disebut dengan

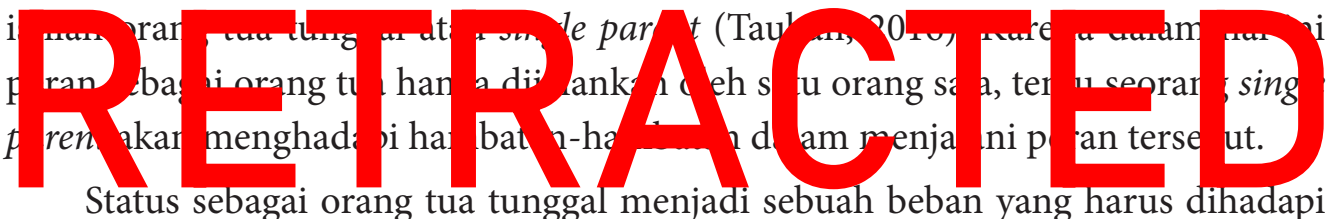
oleh seseorang yang telah berpisah dengan pasangannya. Akibat adanya perpisahan tersebut, anak akan merasa kehilangan sosok yang berarti baginya. Dalam beberapa kasus, anak-anak dengan orang tua tunggal sering kali mengalami hambatan dalam melakukan suatu hal dibandingkan dengan anak-anak dari keluarga dengan orang tua utuh. Selain itu, rata-rata anak dengan orang tua tunggal akan cenderung mengalami perubahan sikap. Contohnya adalah perubahan sikap anak yang awalnya periang menjadi lebih pendiam, lalu anak yang tadinya mandiri menjadi anak yang manja, serta anak yang awalnya rajin menjadi malas (Turban \& Ehrensaft, 2018). Ataupun yang lebih parahnya lagi mengalami perubahan perilaku gender dan orientasi seksual.

Kondisi anak yang hidup tanpa adanya salah satu peran dari ibu atau ayah, dapat menyebabkan kesimpangsiuran pada peran gender anak. Hal ini terjadi karena anak-anak yang tinggal dan tumbuh dalam keluarga yang tak utuh, tidak 
dapat mengekspos salah satu identitas gender dari orang tua mereka. Salah satu dampak kekosongan peran tersebut menjelaskan bahwa anak yang hidup dan berkembang tanpa kehadiran ayah dalam mengasuh anak-anaknya, maka akan muncul kesimpangsiuran peran jenis kelamin anak (Hakoyama, 2020). Hal ini menunjukkan bahwa ketidakhadiran salah satu gender orang tua memberi pengaruh terhadap perkembangan gender anak.

Hal tersebut wajar terjadi apabila mengingat bahwa memang pada dasarnya perilaku gender dan orientasi seksual anak akan terbentuk dari adanya interaksi dan pengalaman sosial anak dengan orang tuanya (Mesman \& Groeneveld, 2018). Keluarga merupakan agen sosialisasi yang memberikan pemahaman positif pada anak mengenai identitas gender. Perilaku dan sikap orang tua pada anak akan turut mengonstruksi identitas yang terekam oleh anak dan tidak bisa dipungkiri bahwa efek dari pendidikan keluarga yang bias gender akan berpengaruh pada karakter dan

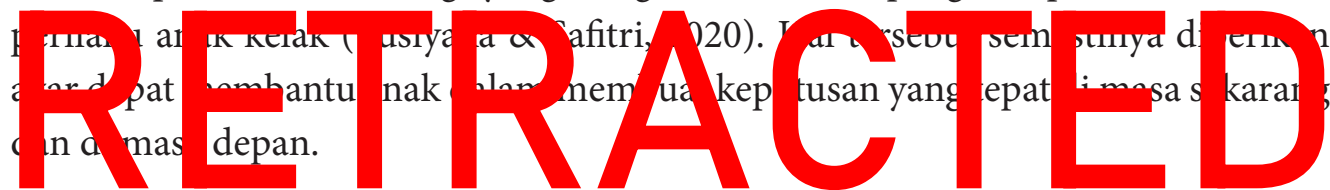

Berdasarkan beberapa permasalahan yang terjadi pada anak dari keluarga single parent di atas, peneliti melihat adanya gap penelitian dengan mengkaji mengenai segala aspek pembentukan identitas gender anak yang dilakukan oleh orang tua tunggal. Khususnya terhadap orang tua tunggal yang memiliki jenis kelamin berbeda dengan anaknya. Hal ini menjadi penting dan menarik untuk diteliti, mengingat adanya urgensi mengenai perubahan dalam proses relasi gender pada orang tua tunggal, dimana terdapat kekosongan peran ayah atau ibu dalam keluarga untuk memberikan pemahaman dalam membentuk identitas gender anak. Artikel ini akan berfokus dalam menelaah proses sosialisasi dan peran kognisi orang tua tunggal dalam pembentukan identitas gender anak, dan mengkaji bagaimana relasi gender yang dilakukan oleh orang tua tunggal dalam pembentukan identitas gender pada anak.

Pendekatan penelitian ini adalah kualitatif dengan metode studi literatur kualitatif berdasarkan tinjauan kritis dari literatur baik teoritis maupun empiris, dari berbagai sumber baik buku maupun jurnal yang disajikan secara deskriptif. Penelaahan ini bersifat teoritis dan empiris dengan bersumber pada pengumpulan data dari berbagai referensi sebagai data pendukung pemaparan penelitian. Pada artikel ini akan berfokus proses perubahan relasi gender, pada orang tua tunggal yang memiliki identitas gender berbeda dengan anaknya sehingga mempengaruhi proses pembentukan identitas gender pada anak. 


\section{Teori Belajar Sosial dan Pembentukan Identitas Gender Pada Anak}

\section{Teori Belajar Sosial (Social Learning Theory)}

Teori Belajar Sosial (Social Learning Theory) ini dikemukakan oleh seorang tokoh yang bernama Albert Bandura merupakan penggagas konsep sosialisasi yang mencakup pada pemberian penguatan pada tingkah laku yang dikendaki secara sosial. Pada fase awal mengenai identitas gender didapatkan oleh anak melalui agen sosialisasi di lingkungan sekitarnya khususnya adalah orang tua (Ainiyah, 2017).

Dalam teori belajar sosial, orang tua berperan penting pada proses sosialisasi identitas gender pada anak. Sosialisasi tersebut dapat dilakukan dengan memberikan penguatan (reinforcement) berupa reward atau punishment bagi anak. Misalnya, masyarakat atau orang tua mengharapkan pria menjadi sosok yang lebih aktif, dan

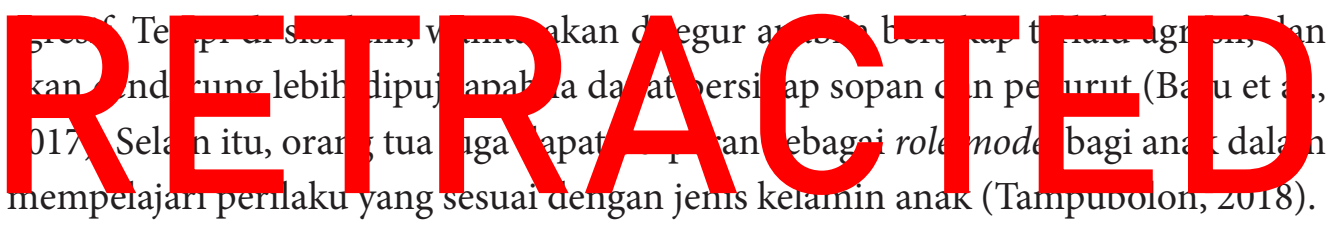

Jadi apabila dijabarkan, dalam proses pembelajaran sosial terdapat metode dasar yaitu, 1) Peniruan (modeling) dan 2) Penguatan (reinforcement) dari lingkungan sosial (Ainiyah, 2017). Pada proses peniruan (modeling) merupakan masa dimana anak mulai memilih untuk meniru perilaku orang tuanya, teman sebaya, maupun orang dewasa, bahkan karakter model dari media sosial elektronik. Kemudian pada komponen peniruan (modeling), seseorang meniru tindakan yang telah mereka amati tersebut dan pada internalisasi dimaksudkan, bahwa proses mengobservasi model inilah yang akan menjadi kekuatan atau landasan bagi anak dalam mempelajari tingkah laku seseorang berdasarkan gender (maskulin dan feminin) oleh apa yang mereka amati di lingkungan sekitar.

Sementara proses penguatan (reinforcement) dalam pembentukan identitas gender dalam teori ini dimaksudkan pada pemberian reward dan punishment terhadap tingkah laku yang dilakukan oleh anak. Dengan adanya pemberian 2 metode dasar yakni peniruan (modeling) dan penguatan (reinforcement) inilah, secara langsung orang tua telah memengaruhi perkembangan gender anak sesuai dengan gender mereka masing-masing. Hal ini dapat meningkatkan kemungkinan adanya pengulangan pada anak dalam berperilaku sesuai dengan harapan orang tuanya tersebut (Suwartini, 2016). 


\section{Pembentukan Identitas Gender pada Anak}

Berbicara tentang gender tidak bisa lepas dari latar belakang sosiologis dan historis yang menyertainya. Gender merujuk kepada identitas kultural yang dipakai untuk membedakan peran, perilaku, mentalitas dan karakteristik antara perempuan dan laki-laki dalam konteks sosial masyarakat. Sedangkan konsep gender berkaitan dengan sifat yang melekat pada perempuan maupun laki-laki yang dikonstruksikan secara sosial dan kultural disebut sebagai identitas gender (Fausto-Sterling, 2019).

Ketika kita membahas mengenai identitas gender, pasti saja sering dikaitkan

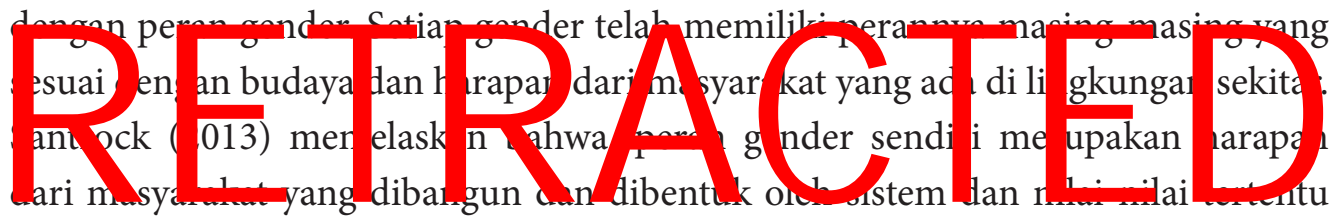

terkait dengan bagaimana seorang individu harus bertingkah laku feminin atau maskulin sesuai dengan jenis kelaminnya. Terdapat tiga hal yang mempengaruhi perkembangan identitas gender, yaitu pengaruh biologis, sosial, dan kognitif.

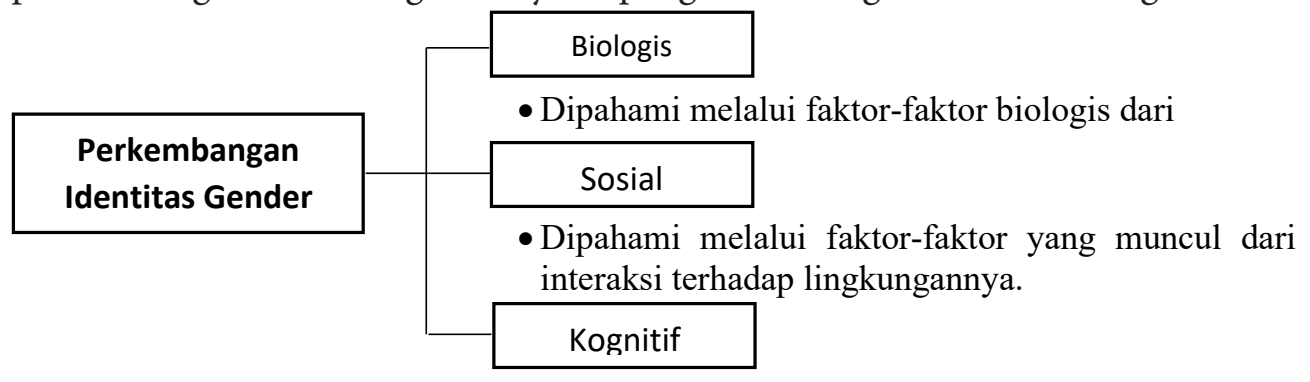

- Dipahami bahwa pembagian gender terjadi setelah berfikir dan memilih aktivitas/objek secara konsisten bahwa dirinya laki-laki atau perempuan

\section{Gambar 1. Perkembangan Identitas Gender Sumber: Pujisatuti (2014)}

Pada konsepsi perkembangan seorang anak dapat memiliki identitas gender dipahami melalui faktor-faktor yang muncul seperti adanya pengaruh biologis dari keturunan. Kemudian pada pengaruh sosial dipahami dari adanya interaksi antara seorang anak terhadap lingkungannya, baik dalam keluarga, budaya, masyarakat, media maupun sekolah. Sementara, proses perkembangan gender anak terjadi setelah anak berfikir bahwa dirinya laki-laki atau perempuan, setelah mereka secara konsisten menyadari bahwa dirinya laki-laki atau perempuan dengan memilih aktivitas, objek, dan sikap hal itu dinamakan pengaruh kognitif. 


\section{Proses Sosialisasi dan Peran Kognisi Orang tua Tunggal dalam Pembentukan Identitas Gender pada Anak}

Identitas gender tidak hanya berbicara mengenai aspek biologis antara perempuan dan laki-laki. Menurut Tampubolon (2018) identitas gender mengarah pada kesadaran tentang bagaimana gender tidak hanya sebatas pengetahuan tetapi juga adanya pemahaman dan penerimaan diri terhadap salah satu jenis kelamin. Identitas gender tidak dapat dipisahkan dari adanya peran gender, yang mana peran tersebut juga disesuaikan atas sosial kultural lingkungan tempat seorang anak tumbuh.

Peran gender menjadi bentuk ekspektasi yang mengarahkan anak mengerti, bertindak, dan berpikir sesuai jenis kelaminnya melalui perilaku dalam sosial kultural tertentu. Orang tua memiliki pengaruh dalam perjalanan seorang anak dalam perkembangan gendernya. Namun, pada orang tua tunggal adanya

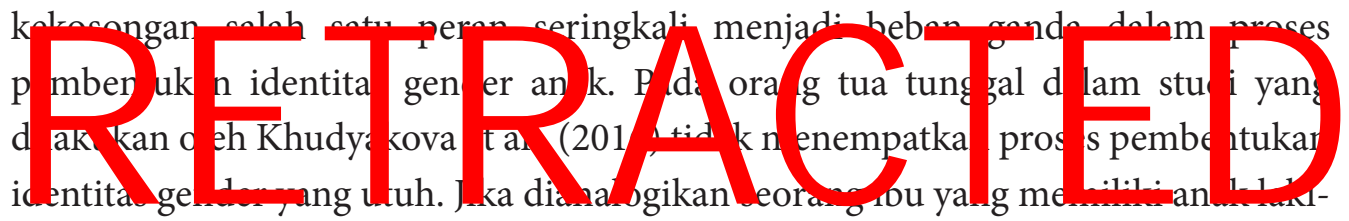

laki lebih banyak menjadikan level feminimitas yang diperoleh akan lebih tinggi dibandingkan level maskulinnya. Ketidakhadiran peran ayah menjadikan seorang anak akan merasakan ketimpangan dalam pembentukan identitas gendernya.

Kesadaran seorang anak tentang pentingnya identitas gender mengenai jenis kelamin mereka sendiri, akan lebih baik jika diamati dari perilaku orang tua mereka yang memiliki kesamaan gender dengan dirinya. Anak-anak dapat memeprtimbangkan perilaku mana yang dianggap sesuai jenis kelaminnya, sehingga akan membentuk pemahaman sifat gender dan konsistensi gender (Endendijk et al., 2018). Tahapan seorang anak dalam memahami proses pembentukan identitas gendernya perlu dilakukan, dengan mekanisme kemampuan kognitif yang dimiliki orang tua itu sendiri dalam mengarahkan pada jenis gender anaknya. Dalam perspektif Kohlberg, diyakini bahwa pemahaman gender menjadi dasar yang penting dalam pengembangan identitas gender pada anak.

Skema struktur kognitif yang perlu dilakukan orang tua tunggal harus mengarahkan pada cara seorang anak dalam memandang gender sebagai informasi dan standar sosial yang memandu perilakunya. Arahan ini menjadi penting karena dapat menjadi salah satu pembentuk skema gender yang akan dimiliki oleh anak. Skema gender sendiri diartikan menjadi bentuk motivasi untuk bertindak sesuai 
dengan norma gender yang berlaku. Proses sosialisasi yang dilakukan orang tua tunggal kepada seorang anak tidak dilakukan secara langsung, tetapi seorang anak memperoleh pengetahuan gender dilihat dari perilaku yang dicontohkan (Endendijk et al., 2016). Penerapan dalam pembentukan identitas gender ini yang perlu dilakukan oleh orang tua tunggal, tidak hanya secara naluri baik dari biologis semata, tetapi perlunya penerapan norma budaya berbasis gender dalam lingkungan keluarga.

Dalam hal ini, orang tua memainkan peran penting terkait konten skema gender seorang anak, sebab anak-anak akan mencariinformasigender dilingkungan terdekat mereka, termasuk keluarganya, dan membentuk stereotipe berdasarkan perilaku

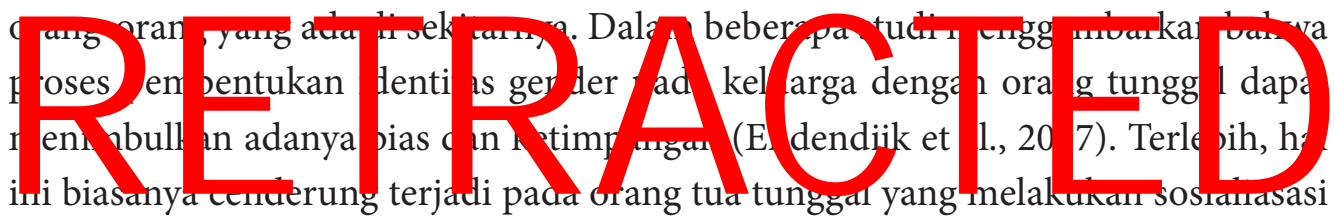
gender kepada anaknya yang memiliki jenis kelamin berbeda. Karena pada proses sosialisasinya, gender dikonseptualisasikan menimbulkan prasangka dan sterotip gender. Terlebih kekosongan salah satu peran gender dari orang tua akan dapat menambah biasa dan ketimpangan tersebut. Gambaran hubungan peran kognisi orang tua dan anak dalam pembentukan identitas gender tercermin pada bagan berikut ini:

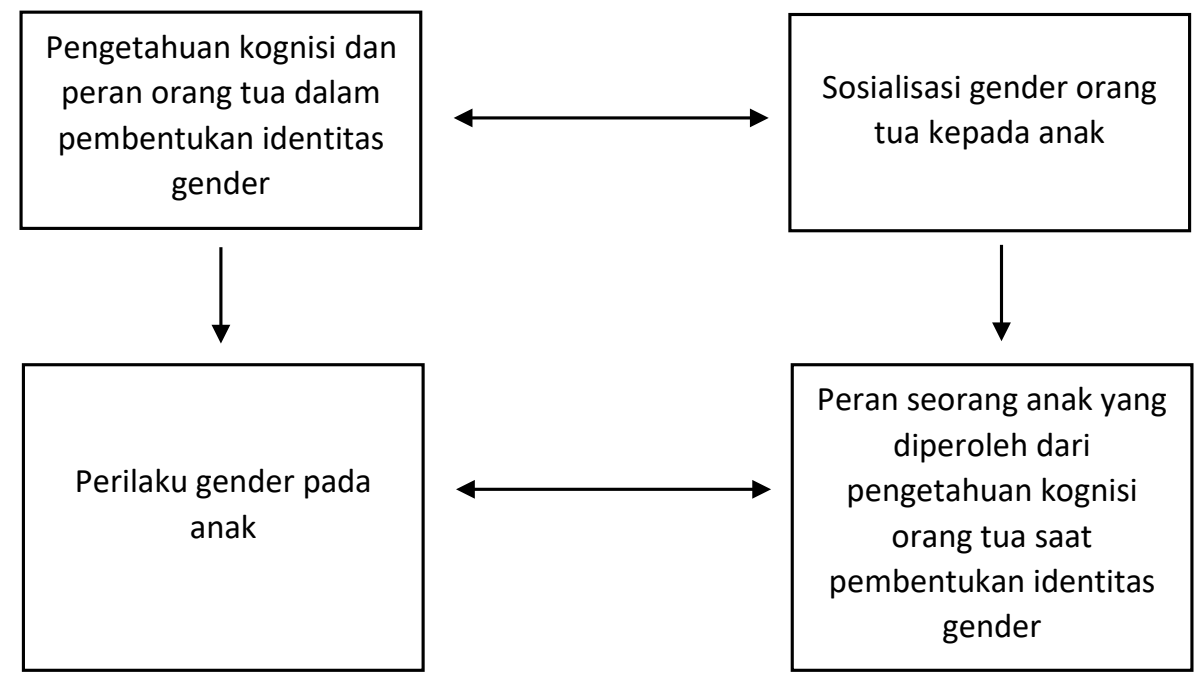

Gambar 2. Hubungan Peran Kognisi Orang tua dan Anak dalam Pembentukan Identitas Gender 
Berdasarkan gambar 2 tersebut dapat dikaitkan dengan aspek pembelajaran sosial yang memberikan prediksi penting berkaitan dengan hubungan antara sosialisasi orang tua dan anak dalam proses pembentukan identitas gendernya. Pada prinsipnya, pembelajaran sosial dalam pembentukan identitas gender ini membentuk model imitasi dan penguatan (Endendijk et al., 2018). Seorang anak mengobservasi perilaku orang tuanya, sehingga anak memahami peran gendernya dengan cara meniru. Ketidakhadiran salah satu peran orang tua dalam pembentukan identitas gender secara tidak langsung memberikan kehilangan peran gender lainnya. Oleh karena itu, bagi anak yang dibesarkan dengan orang tua tunggal khususnya orang tua yang berbeda jenis kelamin, akan sulit bagi anak tersebut untuk membentuk citra gender yang jelas (Chen et al., 2019).

Peran gender dalam pengasuhan anak juga mempengaruhi orang tua mereka dalam bersikap. Orang tua tunggal cenderung lebih memperhatikan perilaku anakanak mereka, yang mereka butuhkan lebih banyak konsisten dengan ciri-ciri peran gender secara tradisional. Adanya ketidakseimbangan pihak lain, menjadikan

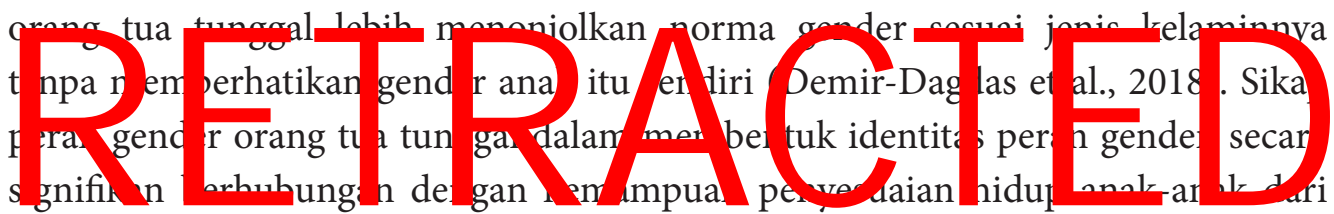

orang tua tunggal itu sendiri. Dalam pembentukan identitas gender anak-anak yang berbeda jenis kelamin dengan orang tua tunggalnya, menunjukkan perbedaan dalam tingkat harga diri dan koping strategi mereka. Dengan demikian, hal ini berkaitan erat dengan kapasitas adaptif yang berdampak pada kepribadian anak itu sendiri (Huang et al., 2012).

Dengan demikian, proses sosialisasi dan peran kognisi orang tua tunggal dalam pembentukan identitas gender pada anak dianggap dapat menjadi aspek penting dalam tumbuh kembang seorang anak. Pembentukan identitas gender melalui proses sosialisasi pada orang tua tunggal mendapatkan tantangan tersendiri berkenaan dengan kekosongan salah satu gender pada anak. Hal ini diperlukan kognisi peran orang tua tunggal untuk bersikap terbuka dalam pembelajaran sosial, berupa pembentukan identitas gender melalui proses penguatan.

\section{Relasi Gender yang Dilakukan oleh Orang Tua Tunggal dalam Pembentukan Identitas Gender pada Anak}

Pola relasi gender dalam sebuah institusi keluarga terbentuk dari sekumpulan pola nilai dan tatanan yang menyesuaikan dengan lingkungan tempat keluarga itu 
tumbuh. Berbagai pola relasi gender ada yang mengarah pada bentuk dominasi patriarkis hingga matriarkis. Bagi keluarga yang bercerai, seorang orang tua tunggal tentu terdapat ketidakseimbangan dalam pembentukan identitas gender. Adanya ketidakseimbangan pola relasi tersebut terjadi, karena ketimpangan peran orang tua tunggal dalam membesarkan seorang anak dengan mendominasikan peran salah satu jenis kelamin orang tua tunggal terhadap anaknya (Aisyah, 2014).

Relasi gender perlu dibangun dengan pemahaman orang tua secara kognisi dan perilaku dalam mengkonseptualisasikan sosialisasi gender yang diterima oleh seorang anak. Pembentukan identitas gender yang diperoleh dari proses belajar sosial baik melalui observasi hingga peniruan perilaku gender, menjadi aspek yang perlu diperhatikan oleh orang tuanya (Wardhani, 2016). Anak yang diasuh dengan kelekatan erat dengan figur salah satu jenis kelamin orang tuanya memberikan kekosongan peran gender yang diterima oleh seorang anak. Anak-anak dari

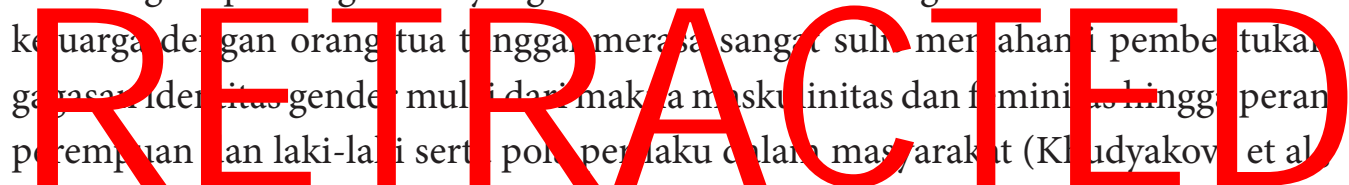
2016). Anak-anak dibesarkan dalam orang tua tunggal dengan jenis kelamin yang berbeda dengan anaknya seringkali dapat dicirikan oleh keterasingan emosional dari orang tua kepada anak, dan formasi dari hubungan simbiosis satu sama lain.

Pada orang tua tunggal yang memiliki jenis kelamin berbeda dengan anak, tentu hal ini menjadi bentuk ketidakseimbangan dan adanya kekosongan peran salah satu relasi gender yang seharusnya dibangun. Seorang anak misalnya yang tumbuh dengan Ibu mereka otomatis lebih banyak menerapkan pola asuh yang bersifat matriarkhis kepada anak lelakinya. Secara tidak langsung, hal ini menimbulkan adanya ketidakseimbangan dalam pola relasi dalam rangka pembentukan identitas gender pada anak. Dampak jangka panjangnya memunculkan konteks yang mengarah pada bentuk ketidakadilan gender, karena ada pola relasi yang terkesan dipaksakan oleh orang tuanya. Realitasnya menunjukkan bahwa pola relasi dalam pembentukan identitas gender ini mengalami proses dehumanisasi (Pujisatuti, 2014b). Ketimpangan relasi gender yang harmonis terbentuk pada diri anak dengan jenis kelamin berbeda dengan orang tua tunggal yang membesarkannya.

Proses pembentukan identitas gender pada anak yang memiliki jenis kelamin berbeda dengan orang tua tunggalnya ini, secara tidak langsung menkonsepsikan adanya peran gender yang hilang. Kekhawatiran adanya pergeseran pola relasi gender ini, secara tidak langsung mengarah pada disharmoni yang dapat menjadi 
potensi konflik sewaktu-waktu. Seorang anak yang hidup bersama salah satu orang tua dengan jenis kelamin berbeda, akan mengalami identitas yang timpang.

Menurut Castells (2004) identitas gender terbentuk melalui proses yang diantaranya adalah, legitimizing identity, resistance identity, dan project identity. Pada proses legitimizing identity, seorang anak mengalami pandangan gender yang dianggap paradoks. Dalam satu sisi, seorang anak membutuhkan sosialisasi gender dari orang tua dengan memiliki jenis kelamin yang sama secara nyata dan menjadi bentuk legitimasi terhadap sebuah identitas gender. Namun di sisi lain, seringkali adanya intimidasi yang didominasi oleh orang tua tunggal ini menimbulkan

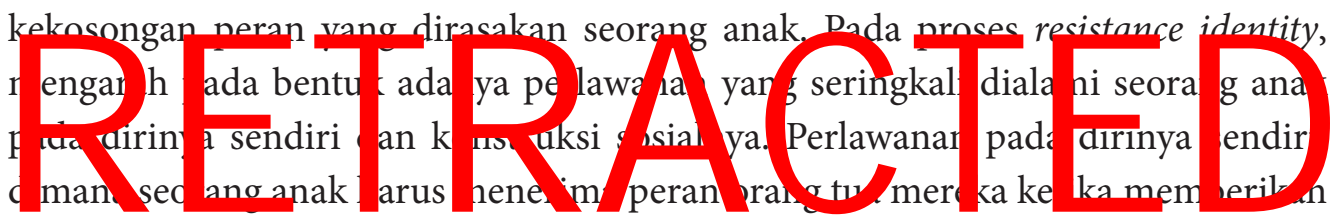
pembentukan identitas gender. Berbeda dengan aspek sosialnya, seringkali seorang anak berjuang melawang stigma negatif yang dialami dalam dirinya. Proses akhirnya pun berupa project identity ini menjadi bentuk alternatif yang seringkali membuat seorang anak membangun identitas barunya dan meredefinisi makna gender.

Dengan demikian, berkenaan dengan relasi gender yang dilakukan oleh orang tua tunggal dalam pembentukan identitas gender anak, tidak hanya berkenaan dengan makna gender dari aspek biologis, tetapi pentingnya pemaknaan identitas gender secara sosial dan kultural. Konsep pembentukan identitas gender perlu dibangun tanpa mengaburkan peran salah satu gender yang dominan. Anak yang mengalami kehilangan panutan dalam proses pembentukan identitas gendernya pun lekat dengan disharmoni yang dialami berupa kekosongan peran. Maka dari itu, pentingnya bagi orang tua tunggal memahami dan memiliki pengetahuan gender dinilai dapat meminimalisir konflik psikologis dalam pertumbuhan seorang anak.

\section{Simpulan}

Proses pembentukan identitas gender yang mengarah pada peran gender seorang anak tidak hanya berbicara mengenai aspek biologi, tetapi berkenaan dengan aspek sosial dan kulturalnya. Orang tua tunggal menghadapi tantangan dan kesulitan tersendiri ketika ia mendidik anaknya yang berbeda gender. Hal ini ditandai dengan proses sosialisasi yang tidak lengkap atau terdapat ketimpangan dalam proses pembelajaran sosial identitas gendernya. Adanya dominasi norma gender saat sosialisasi pembentukan identitas gender mengaburkan peran salah satu 
gender, sehingga makna gender dianggap bias. Hal ini dapat memberikan dampak jangka panjang berupa proses pembentukan identitas gendernya pun lekat dengan disharmoni yang dialami berupa kekosongan peran gender.

Meskipun demikian hal tersebut bisa diminimalisir sedemikian rupa dengan berbagai praktik terutama peran serta keluarga besar dan pemahaman yang mendasar oleh orang tua mengenai peran gender. Peran serta keluarga besar menjadi penting terutama dalam membimbing proses pertumbuhan dan pengenalan berbagai peran sosial termasuk peran gender yang harus dilakukan oleh sang anak. Begitu pula pemahaman mendasar mengenai peran gender juga harus menjadi poin penting yang harus dipahami oleh orang tua. Orang tua mempunyai peran yang penting dalam menanamkan bahwa peran gender adalah peran yang dikonstruksi secara sosial oleh masyarakat sehingga anak harus mengenal peran-peran apa saja, nilai dan norma apa saja yang terdapat dalam masyarakat. Sehingga pemahaman anak akan terbentuk terutama mana yang menjadi kewajiban dan mana yang menjadi
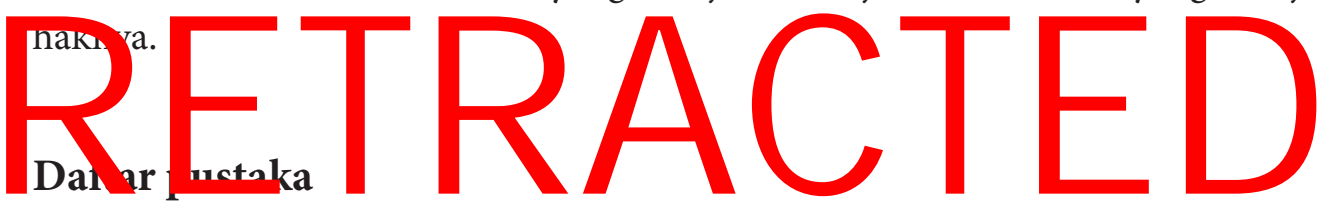

Ainiyah, Q. (2017). Social Learning Theory dan Perilaku Agresif Anak dalam Keluarga. Jurnal Ilmu Syariah Dan Hukum, 2(1), 94-98.

Aisyah, N. (2014). Relasi Gender dalam Institusi Keluarga. Muwazah, 5(2), 32-54.

Basu, S., Zuo, X., Lou, C., Acharya, R., \& Lundgren, R. (2017). Learning to Be Gendered: Gender Socialization in Early Adolescence Among Urban Poor in Delhi, India, and Shanghai, China. Journal of Adolescent Health, 61(4), S24S29. https://doi.org/10.1016/j.jadohealth.2017.03.012

Castells, M. (2004). The Power of Identity. Oxford University Press.

Chen, I. J., Zhang, H., Wei, B., \& Guo, Z. (2019). The Model of Children's Social Adjustment under The Gender-roles Absence in Single-Parent Families. International Journal of Psychology, 54(3), 316-324. https://doi.org/10.1002/ ijop.12477

Demir-Dagdas, T., Isik-Ercan, Z., Intepe-Tingir, S., \& Cava-Tadik, Y. (2018). Parental Divorce and Children From Diverse Backgrounds: Multidisciplinary Perspectives on Mental Health, Parent-Child Relationships, and Educational Experiences. Journal of Divorce and Remarriage, 59(6), 469-485. https://doi. org/10.1080/10502556.2017.1403821 
Endendijk, J. J., Groeneveld, M. G., Bakermans-kranenburg, M. J., \& Mesman, J. (2016). Gender-Differentiated Parenting Revisited: Meta-Analysis Reveals Ver ... Gender-Differentiated Parenting Revisited : Meta-Analysis Reveals Ver ... Plos One, 11(7), 3-33. https://doi.org/10.7910/DVN/P6X6XC.Funding

Endendijk, J. J., Groeneveld, M. G., \& Mesman, J. (2018). The Gendered Family Process Model: An Integrative Framework of Gender in the Family. Archives of Sexual Behavior, 47(4), 877-904. https://doi.org/10.1007/s10508-018-1185-8

Endendijk, J. J., Groeneveld, M. G., van der Pol, L. D., van Berkel, S. R., HallersHaalboom, E. T., Bakermans-Kranenburg, M. J., \& Mesman, J. (2017). Gender Differences in Child Aggression: Relations With Gender-Differentiated Parenting and Parents' Gender-Role Stereotypes. Child Development, 88(1), 299-316. https://doi.org/10.1111/cdev.12589

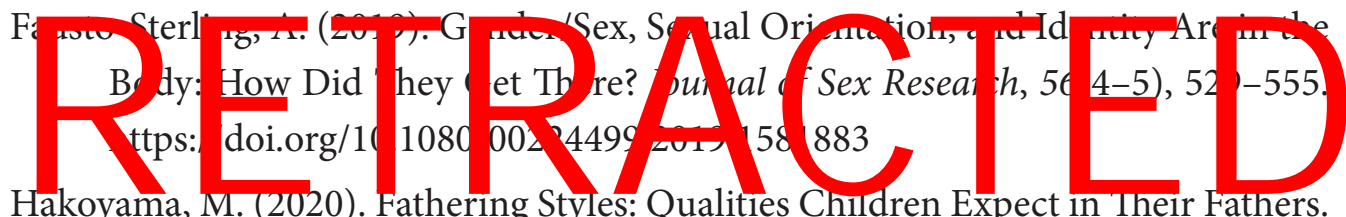

Marriage and Family Review, 56(5), 391-424. https://doi.org/10.1080/014949 29.2020 .1726851

Huang, X., Zhu, X. L., Zheng, J., Zhang, L., \& Shiomi, K. (2012). Relationships among Androgyny, Self-Esteem, and Trait Coping Style of Chinese University Students. Social Behavior and Personality, 40(6), 1005-1014. https://doi. org/10.2224/sbp.2012.40.6.1005

Khudyakova, T. L., Gridyaeva, L. N., \& Klepach, Y. V. (2016). Specific Features of Gender Identity Formation in Children from Single-parent and Nuclear Families in Ontogenesis. Procedia - Social and Behavioral Sciences, 233(May), 393-396. https://doi.org/10.1016/j.sbspro.2016.10.167

Mesman, J., \& Groeneveld, M. G. (2018). Gendered Parenting in Early Childhood: Subtle But Unmistakable if You Know Where to Look. Child Development Perspectives, 12(1), 22-27. https://doi.org/10.1111/cdep.12250

Pujisatuti, T. (2014a). Peran Orang Tua dalam Pembentukan Identitas Gender Anak. Jurnal Ilmiah Syiar, 14(1), 53-62.

Pujisatuti, T. (2014b). Peran Orang Tua dalam Pembentukan Kepribadian Anak. Syiar, 14(1), 53-62.

Santrock, J. W. (2013). Adoslence Perkembangan Remaja. 
Suwartini, S. (2016). Teori Kepribadian Social Cognitive : Kajian Pemikiran Albert Bandura. Al-Tazkiah: Jurnal Bimbingan Dan Konseling Islam, 5(1), 37-46.

Tampubolon, G. N. (2018). Identitas dan Peran Gender pada Anak Usia 3-7 Tahun dalam Keluarga Komuter. Jurnal CARE (Children Advisory Research and Education), 6(1), 1-9.

Taubah, M. (2016). Pendidikan Anak dalam Keluarga Perspektif Islam. Jurnal Pendidikan Agama Islam, 3(1), 109-136. https://doi.org/10.15642/ jpai.2015.3.1.109-136

Turban, J. L., \& Ehrensaft, D. (2018). Research Review: Gender Identity in Youth: Treatment Paradigms and Controversies. The Journal of Child Psychology and Psychiatric, 59(12), 1228-1243. https://doi.org/10.1111/jcpp.12833

Wardhani, W. D. L. (2016). Constructing Gender Identity in Early Children.

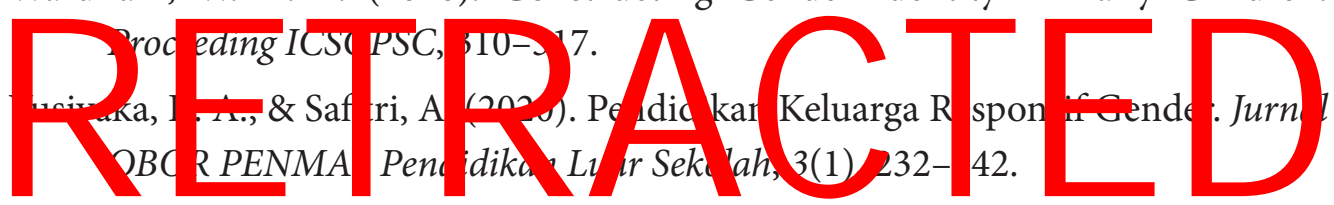


